\title{
Detection of knockdown resistance ( $k d r)$ mutations in Anopheles gambiae: a comparison of two new high-throughput assays with existing methods
}

\author{
Chris Bass*†1, Dimitra Nikou ${ }^{\dagger 2}$, Martin J Donnelly², Martin S Williamson¹, \\ Hilary Ranson ${ }^{3}$, Amanda Ball${ }^{2}$, John Vontas ${ }^{4}$ and Linda M Field ${ }^{1}$
}

Address: ${ }^{1}$ Department of Biological Chemistry, Rothamsted Research, Harpenden, AL5 2JQ, UK, ${ }^{2}$ Vector Group, Liverpool School of Tropical Medicine, Pembroke Place, Liverpool L35QA, UK, ${ }^{3}$ Division of Cell and Molecular Biology, Sir Alexander Flemming Building, Imperial College, London, UK and ${ }^{4}$ Laboratory of Pesticide Science, Agricultural University of Athens, Iera Odos 75, 118 55, Votanikos, Athens, Greece

Email: Chris Bass* - chris.bass@bbsrc.ac.uk; Dimitra Nikou - dnikou@liv.ac.uk; Martin J Donnelly - m.j.donnelly@liverpool.ac.uk; Martin S Williamson - martin.williamson@bbsrc.ac.uk; Hilary Ranson - h.ranson@imperial.ac.uk; Amanda Ball - ajball@liverpool.ac.uk; John Vontas -vontas@aua.gr; Linda M Field - lin.field@bbsrc.ac.uk

* Corresponding author †Equal contributors

Published: 13 August 2007

Malaria Journal 2007, 6:III doi:10.1 I86/I475-2875-6-III
Received: 16 April 2007

Accepted: 13 August 2007

This article is available from: http://www.malariajournal.com/content/6/I/III

(C) 2007 Bass et al; licensee BioMed Central Ltd.

This is an Open Access article distributed under the terms of the Creative Commons Attribution License (http://creativecommons.org/licenses/by/2.0), which permits unrestricted use, distribution, and reproduction in any medium, provided the original work is properly cited.

\begin{abstract}
Background: Knockdown resistance $(k d r)$ is a well-characterized mechanism of resistance to pyrethroid insecticides in many insect species and is caused by point mutations of the pyrethroid target site the para-type sodium channel. The presence of $k d r$ mutations in Anopheles gambiae, the most important malaria vector in Africa, has been monitored using a variety of molecular techniques. However, there are few reports comparing the performance of these different assays. In this study, two new high-throughput assays were developed and compared with four established techniques.
\end{abstract}

Methods: Fluorescence-based assays based on I) TaqMan probes and 2) high resolution melt (HRM) analysis were developed to detect $k d r$ alleles in An. gambiae. Four previously reported techniques for $k d r$ detection, Allele Specific Polymerase Chain Reaction (AS-PCR), Heated Oligonucleotide Ligation Assay (HOLA), Sequence Specific Oligonucleotide Probe - Enzyme-Linked ImmunoSorbent Assay (SSOP-ELISA) and PCR-Dot Blot were also optimized. The sensitivity and specificity of all six assays was then compared in a blind genotyping trial of 96 single insect samples that included a variety of $k d r$ genotypes and African Anopheline species. The relative merits of each assay was assessed based on the performance in the genotyping trial, the length/difficulty of each protocol, cost (both capital outlay and consumable cost), and safety (requirement for hazardous chemicals).

Results: The real-time TaqMan assay was both the most sensitive (with the lowest number of failed reactions) and the most specific (with the lowest number of incorrect scores). Adapting the TaqMan assay to use a PCR machine and endpoint measurement with a fluorimeter showed a slight reduction in sensitivity and specificity. HRM initially gave promising results but was more sensitive to both DNA quality and quantity and consequently showed a higher rate of failure and incorrect scores. The sensitivity and specificity of AS-PCR, SSOP-ELISA, PCR Dot Blot and HOLA was fairly similar with a small number of failures and incorrect scores.

Conclusion: The results of blind genotyping trials of each assay indicate that where maximum sensitivity and specificity are required the TaqMan real-time assay is the preferred method. However, the cost of this assay, particularly in terms of initial capital outlay, is higher than that of some of the other methods. TaqMan assays using a PCR machine and fluorimeter are nearly as sensitive as real-time assays and provide a cost saving in capital expenditure. If price is a primary 
factor in assay choice then the AS-PCR, SSOP-ELISA, and HOLA are all reasonable alternatives with the SSOP-ELISA approach having the highest throughput.

\section{Background}

Members of the Anopheles gambiae complex are the major vectors of malaria in sub-Saharan Africa. One of the most effective vector-directed malaria control strategies involves the use of insecticide-treated bednets (ITNs) [14]. The only class of insecticides presently licensed for this purpose are the pyrethroids which show low mammalian toxicity and fast knockdown activity. Unfortunately, the intensive use of pyrethroids, including their indirect use in agriculture, has led to reports of reduced efficacy $[5,6]$.

Pyrethroids act on the insect nervous system by altering the normal function of the para-type sodium channel, resulting in prolonged channel opening that causes increased nerve impulse transmission, leading to paralysis and death $[7,8]$. Resistance to pyrethroids is often associated with alterations (point mutations) in the para-type sodium channel gene, that cause reduced neuronal sensitivity. This resistance mechanism was first identified in the house fly Musca domestica and was termed knockdown resistance or $k d r$ [9]. Subsequent analyses demonstrated that $k d r$ was caused by a leucine to phenylalanine (L1014F) replacement in transmembrane segment 6 of domain II of the sodium channel [10]. Two amino acid substitutions at the same position (L1014F and L1014S) have been reported in pyrethroid resistant An. gambiae initially in An. gambiae s.s. [11,12] and more recently in Anopheles arabiensis $[13,14]$. In several West African countries the predominant $k d r$ mutation in An. gambiae populations is the leucine to phenyalanine substitution (L1014F) termed $k d r$ west ( $k d r$-w), whilst in East African populations the leucine to serine (L1014S) termed $k d r$ east ( $k d r-e)$ is more common [14-19]. Recently, individuals heterozygous for both the $k d r$-w and $k d r$-e alleles have been reported $[20,21]$.

Sensitive detection of the mutations associated with resistance is a prerequisite for resistance management strategies aimed at prolonging insecticide life while maintaining sufficient insect control. This type of monitoring requires rapid high-throughput assays and there are currently several different methods available for detecting the DNA changes responsible for $k d r$ in An. gambiae. The most widely used method is based on Allele Specific PCR (ASPCR) $[11,12]$, but more recently a number of other assays have been described including Heated Oligonucleotide Ligation Assay (HOLA) [22], Sequence Specific Oligonucleotide Probe Enzyme-Linked ImmunoSorbent Assay (SSOP-ELISA) [23], PCR-Dot Blot [24], Fluorescence Resonance Energy Transfer (FRET)/Melt Curve analysis [20] and PCR elongation with fluorescence [25]. However, to date there are few reports comparing the performance and relative advantages and disadvantages (safety, cost, speed, simplicity etc.) of these assays under comparable conditions. Here a single blind comparison of the performance of four of these assays with two newly developed fluorescence-based high-throughput assays (TaqMan and High Resolution Melt - HRM) was carried out using a 96 sample reference plate containing DNAs from a variety of field-collected Anopheles individuals representing all the known $k d r$ genotypes.

\section{Methods \\ Mosquito collections and preparation of 96 sample reference plate}

For the initial optimisation of each assay mosquitoes were either obtained from two laboratory colonies, Kisumu (susceptible line from Kenya) and RSP (homozygous for the East African $k d r$ mutation), or were field-caught samples from Burkina Faso, Ghana, Kenya and Cameroon. Genotypes of individuals were confirmed by sequencing of the relevant region of the para-type sodium channel gene as described previously [12].

All detection assays were performed on a standard 96 well test plate. The 96 sample test plate was comprised of genomic DNA of representative mosquito individuals of all the known $k d r$ genotypes including three individuals heterozygous for both the east and west $k d r$ alleles. The plate included DNA from An. gambiae s.s (both S and M forms) An. arabiensis, Anopheles quadriannulatus, Anopheles melas, Anopheles merus and Anopheles funestus. The amount of DNA was variable between samples to test the sensitivity of each assay. DNA concentration was determined by absorption at $260 \mathrm{~nm}$ using a NanoDrop spectrophotometer (NanoDrop Technologies). The plate also included a number of Plasmodium falciparum DNA samples and water blanks as negative controls. The details of each of the 96 samples (including species, molecular form, collection location, DNA concentration and $k d r$ genotype) is given in Additional file 1. This information was withheld from the persons who carried out the testing of each assay to ensure no bias occurred in the scoring of results. For all samples DNA was extracted from single mosquitoes using either the Livak or Ballinger Crabtree methods [26,27] or DNAzol reagent (Molecular Research Center, Inc) at onefifth the recommended reagent volume for each extraction. The DNAs were resuspended in either TE buffer or sterile water at volumes between 100 and $200 \mu \mathrm{l}$. Species identification was carried out using an established PCR 
assay [28] and specimens had been assigned a putative $k d r$ genotype by AS-PCR [11,12], HOLA [22] or DNA sequencing. After the blind genotyping trials any samples of ambiguous $k d r$ genotype were sequenced.

\section{AS-PCR}

AS-PCR was carried out following the methods in the original descriptions of AS-PCR for $k d r$ detection in Anopheles $[11,12]$. Two reported methods of modifications to these assays were also investigated [20,29]. All four protocols were performed using three different DNA polymerases/ master mixes, Dynazyme II (Finzymes), PCR master mix (Promega) HotStarTaq Plus Master Mix Kit (Qiagen) and three different PCR machines a GeneAmp ${ }^{\mathrm{TM}}$ PCR System 2700 a Techne Genius and a Techne Progene. In all cases amplifications were performed in $25 \mu$ reactions using 1 $\mu$ template. After comparison of all protocols/polymerase kits the protocol of Verhaeghen et al [20] using the $2 \times$ PCR master mix (Promega) was selected to genotype the 96 sample reference plate.

\section{TaqMan}

Previous work characterizing the para gene region encoding domain II S4-S6 of the sodium channel from a range of insect species has shown that this region contains an intron very close to the $k d r$ mutation site. In many insect species this intron shows a degree of variation (nucleotide substitutions or insertions/deletions) between different stains/isolates which would affect the performance of any assay that uses primer binding sites within this region. Therefore, nucleotide alignments of all the An. gambiae and An. arabiensis domain II sodium channel gene sequences available in the National Center for Biotechnology Information (NCBI) database were compared and a region around the $k d r$ site which was conserved in all isolates/species was selected for primer/probe design.

Forward and reverse primers and three minor groove binding (MGB) probes (Applied Biosystems) were designed using the Primer Express ${ }^{\mathrm{TM}}$ Software Version 2.0. Primers $k d r$-Forward (5'-CATTTTTCTTGGCCACTGTAGTGAT-3'), and $k d r$-Reverse (5'-CGATCTTGGTCCATGTTAATTTGCA-3') were standard oligonucleotides with no modification. The probe WT (5'-CTTACGACTAAATTTC$\left.3^{\prime}\right)$ was labelled with VIC at the 5 ' end for the detection of the wildtype allele, the probes $k d r \mathrm{~W}$ (5'ACGACAAAATTTC-3') and $k d r$ E (5'-ACGACTGAATTTC3 ') were labelled with 6-FAM for detection of the $k d r-\mathrm{w}$ and $k d r$-e alleles respectively. Each probe also carried a 3' non-fluorescent quencher and a minor groove binder at the 3 ' end. The minor groove binder provides more accurate allelic discrimination by increasing the $T_{M}$ between matched and mis-matched probes [30]. The primers $k d r$ Forward and $k d r$-Reverse and the WT probe were used in one assay with probe $k d r \mathrm{~W}$ for $k d r$-w detection and in a second assay with probe $k d r \mathrm{E}$ for $k d r$-e detection.

PCR reactions $(25 \mu \mathrm{l})$ contained $1 \mu \mathrm{l}$ of genomic DNA, $12.5 \mu$ of SensiMix DNA kit (Quantace), $900 \mathrm{nM}$ of each primer and $200 \mathrm{nM}$ of each probe. Samples were run on a Rotor-Gene $6000^{\mathrm{TM}}$ (Corbett Research) using the temperature cycling conditions of: 10 minutes at $95^{\circ} \mathrm{C}$ followed by 40 cycles of $95^{\circ} \mathrm{C}$ for 10 seconds and $60^{\circ} \mathrm{C}$ for $45 \mathrm{sec}-$ onds. The increase in VIC and FAM fluorescence was monitored in real time by acquiring each cycle on the yellow ( $530 \mathrm{~nm}$ excitation and $555 \mathrm{~nm}$ emission) and green channel (470 nm excitation and 510 emission) of the Rotor-Gene respectively.

The TaqMan assays were also performed using a standard PCR machine followed by endpoint measurements using a fluorimeter. For this the PCR reactions were set up as described above and run on a GeneAmp ${ }^{\mathrm{TM}}$ PCR System 2700 (Applied Biosystems) using temperature cycling conditions of: 10 minutes at $95^{\circ} \mathrm{C}$ followed by 40 cycles of $92^{\circ} \mathrm{C}$ for 15 seconds and $60^{\circ} \mathrm{C}$ for 1 minute. Reactions were then transferred to black half-area microtitre plates (Costar) and read in a FLx800 fluorimeter (Biotek) using 485/20 excitation and 528/20 emission filters for FAM detection and 530/25 excitation and 560/10 emission filters for VIC detection. The sensitivity of the FLx800 was adjusted for FAM and VIC fluorescence to achieve the maximum dynamic range without exceeding the maximum threshold. To determine the background level of fluorescence of the assay three or more no template controls were included in each run and the fluorescence values of these reactions averaged and subtracted from all values. To aid in genotype scoring a cut-off threshold was established by subtracting a further percentage of the averaged negative control value to create only positive or negative values. Percentages varied for the different probe fluorophore measurements. For the east and west assay susceptible probes labelled with VIC, an additional 15\% was subtracted. For the $k d r$-w allele specific probe (VIC), an additional $20 \%$ was subtracted and for the $k d r$-e specific probe, an additional $60 \%$ was subtracted. The cut-off values given here were found to work well with the master mix and conditions described above. However, when using different master mixes or fluorimeters the cut-off thresholds were found to vary, so if alternative conditions are to be used optimization with templates of known genotype may be required.

\section{HRM}

The design of a HRM assay for $k d r$ detection followed the recommendations in previous reports of this technique [31-33]. The same forward and reverse primers ( $k d r$-Forward and $k d r$-Reverse) that were used in the TaqMan assay were also used for HRM as they efficiently amplified a 
small product of $71 \mathrm{bp}$. PCR reactions contained $1 \mu \mathrm{l}$ of genomic DNA, $12.5 \mu \mathrm{l}$ of SensiMix DNA kit (Quantace), $300 \mathrm{nM}$ of each primer and $1.5 \mu \mathrm{M}$ of SYTO 9 (Invitrogen) made up to $25 \mu \mathrm{l}$ with filter sterilized water. Samples were run on a Rotor-Gene 6000 (HRM) ${ }^{\mathrm{TM}}$ (Corbett Research) using temperature cycling conditions of: 10 minutes at $95^{\circ} \mathrm{C}$ followed by 40 cycles of $95^{\circ} \mathrm{C}$ for 5 seconds and $60^{\circ} \mathrm{C}$ for 10 seconds. This was followed by a melt step of $65-75^{\circ} \mathrm{C}$ in $0.1^{\circ} \mathrm{C}$ increments pausing for 2 seconds per step. The increase in SYTO 9 fluorescence was monitored in real time during the PCR and the subsequent decrease during the melt phase by acquiring each cycle/step to the green channel (470 $\mathrm{nm}$ excitation and $510 \mathrm{~nm}$ emission) of the Rotor-Gene. Genotypes were scored by examining normalized and difference melt plots using the RotorGene Software.

\section{HOLA}

HOLA was carried out following the protocol of Lynd et al [22] with no modification.

\section{SSOP-ELISA}

SSOP-ELISA followed the protocol of Kulkarni et al [23] with slight modifications. Primers AgD1 and AgD2 primers [23] were used to PCR amplify a 293 bp fragment from domain II of the sodium channel gene. The primer AgD2 carries a biotin modification at the $5^{\prime}$ end. PCR was carried out in a $25 \mu$ l volume with a final concentration of $1 \times$ Buffer, $2 \mathrm{mM} \mathrm{MgCl}_{2}, 0.2 \mathrm{mM}$ dNTPs, $0.1 \mu \mathrm{M}$ each primer, $0.034 \mathrm{U} / \mu \mathrm{l}$ Taq DNA polymerase (Qiagen). Reaction conditions were $94^{\circ} \mathrm{C}$ for $5 \mathrm{~min}$ followed by 35 cycles of $94^{\circ} \mathrm{C}$ for $30 \mathrm{sec}, 48^{\circ} \mathrm{C}$ for $40 \mathrm{sec}, 72^{\circ} \mathrm{C}$ for $40 \mathrm{sec}$ and a final extension step of $72^{\circ} \mathrm{C}$ for $10 \mathrm{~min}$. PCR products were diluted $1: 1$ in water, denatured at $95^{\circ} \mathrm{C}$ for five minutes and cooled to $4^{\circ} \mathrm{C}$. The $3^{\prime}$ end digoxigenin-conjugated SSOPs (104F, 104S, 104L) [22] were added together with the diluted PCR products to the streptavidin-coated ELISA plates (Sigma) as described previously [22]. Washes were performed [22] and $100 \mu \mathrm{l}$ of TMB substrate (Roche, 11484281001 ) was added. After five minutes, the reaction was stopped with the addition of $0.5 \mathrm{M} \mathrm{H}_{2} \mathrm{SO}_{4}$ and the optical density at $450 \mathrm{~nm}$ was measured in an ELISA reader.

\section{PCR-Dot Blot}

PCR was carried out as for the SSOP-ELISA method (although in this case the AgD2 primer is unmodified). Amplified DNA products were denatured for $2 \mathrm{~min}$ at $94^{\circ} \mathrm{C}$ and then cooled to $4{ }^{\circ} \mathrm{C}$. One and a half $\mu \mathrm{l}$ of PCR products were spotted onto nylon membranes (Roche) and fixed to them by cross-linking with ultraviolet radiation. Membranes were probed with the $104 \mathrm{~L}, 104 \mathrm{~F}$ and $104 \mathrm{~S}$ probes [22] at $42^{\circ} \mathrm{C}$ for 1.5 hours and then washed twice with $2 \times$ SSC $0.1 \%$ SDS for $5 \mathrm{~min}$ at room temperature, followed by two washings with $0.2 \times$ SSC $0.1 \%$ SDS at $42^{\circ} \mathrm{C}$ for the three $k d r$ alleles (15 minutes per wash). Membranes were then placed in blocking buffer (Roche) for 30 minutes. Probes were detected using a non-radioactive CSPD substrate (Roche) based approach. Alkaline phosphatase-conjugated anti-digoxigenin Fab fragments and CSPD substrate were added to the membranes following manufacturer's instructions. Membranes were finally exposed to Hyperfilm ECL for approximately 6 hours.

\section{Results \\ AS-PCR}

In allele-specific PCR oligonucleotide primers that are designed to be allele specific (by incorporating sequence specific differences between alleles into the 3' end of the primers) are used in PCR in combination with allele nonspecific primers to amplify allele-specific and allele nonspecific 'control' fragments of different sizes. Agarose gel electrophoresis is carried out post-PCR to separate the DNA fragments and score genotypes [34].

A number of different AS-PCR protocols were investigated using several enzyme mixes giving variable results (Figure 1 ). The best results were achieved following the protocol of Verhaeghen et al [20]. This method differs from the others in that it uses a convenient combined temperature cycling program for both east and west $k d r$ assays. Both the Promega PCR and Qiagen HotStar master mixes gave good results (Figure 1), although the Qiagen mix gave slightly greater amplicon yield the Promega mix is cheaper and was therefore chosen to genotype the 96 sample reference plate. Banding patterns were scored by eye and the results are shown in Table 1 and Additional file 1. The results indicate this method is reasonably sensitive with 15 failed reactions (where a genotype could not be determined). Of these four were DNA from An. funestus (which is either very degraded or contains strong inhibitors, see the TaqMan results section) and four from An. merus individuals. The AS-PCR method was also reasonably accurate with only three incorrect scores, probably resulting from difficulties in visual scoring which was affected by variation in the quality of the agarose gels.

\section{TaqMan}

The TaqMan assay is a PCR method employing oligonucleotide probes that are dual-labelled with a fluorescent reporter dye and a quencher molecule. Amplification of the probe-specific product causes cleavage of the probe, generating an increase in reporter fluorescence as the reporter dye is released away from the quencher. By using different reporter dyes, cleavage of allele-specific probes can be detected in a single PCR [35].

After minimal optimization using templates of known genotype both the $k d r$-e and $k d r$-w TaqMan assays showed excellent discrimination of the two resistance alleles. Both 
Table I: Performance of seven assays in the blind kdr genotyping trial. Table shows the number of samples scored correctly, failed to score, or incorrectly scored out of a total of 96 samples.

\begin{tabular}{cccccccc}
\hline & TaqMan & $\begin{array}{c}\text { TaqMan } \\
\text { Endpoint }\end{array}$ & AS-PCR & SSOP-ELISA & PCR Dot Blot & HOLA & HRM \\
\hline $\begin{array}{c}\text { Correct } \\
\text { scores }\end{array}$ & 91 & 87 & 78 & 78 & 79 & 77 & 73 \\
$\begin{array}{c}\text { Failed } \\
\text { reactions }\end{array}$ & 5 & 7 & 15 & 3 & 5 & 12 & 8 \\
Misscores & 0 & 2 & 5 & 16 & 11 & 7 \\
\hline
\end{tabular}

assays use two probes, the first specific for the wildtype allele is labelled with VIC and the second, specific for the mutant allele ( $k d r$-w or $k d r$-e), is labelled with FAM. In either assay a substantial increase in VIC fluorescence indicates a homozygous wildtype, a substantial increase in FAM fluorescence indicates a homozygous mutant and a, usually intermediate, increase in both signals indicates a heterozygote (Figure 2). Individuals homozygous for the $k d r$-e mutation display no increase in VIC or FAM fluorescence in the $k d r$-w assay and vice versa. To help score the genotypes the Rotor-Gene software allows endpoint fluorescence values for the two dyes to be automatically corrected for background and plotted against each other in bi-directional scatter plots (Figure 3). The clustering of samples in scatter plots in addition to the real-time fluorescence traces gives easy and accurate genotype scoring. The results of genotyping the 96 samples in the reference plate are given in Table 1/Additional file 1 showing that the real-time TaqMan assay is sensitive, with only five failed reactions. Of these all but one were DNA samples from An. funestus individuals. Attempts were made to sequence the four An. funestus samples on the plate but repeated attempts to amplify the region of interest were unsuccessful despite over 65 cycles (in two rounds) of PCR. These four samples came from a single source in South Africa and failed to score in any of the genotyping assays so it is likely this DNA was badly degraded or contained strong inhibitors of PCR. Although there are currently no reports of $k d r$ mutations in this species $A n$. funestus samples were obtained from an alternative source, sequenced and run through the TaqMan assays. In this instance, the samples were correctly scored as wildtype indicating that the TaqMan assay can be used to screen this species for the potential emergence of $k d r$. Overall the TaqMan assay demonstrated high specificity in the genotyping trial with no incorrect scores being recorded.

The TaqMan assay can also be adapted to use a standard thermocycler followed by endpoint measurement of VIC and FAM fluorescence with a fluorimeter. Raw fluorescence values were corrected for background and an additional cut-off value (see methods) and again plotted on simple scatter plots to aid genotyping (Figure 4). The results of genotyping the 96 samples in the reference plate showed this method is both sensitive and specific (Table 1/Additional file 1) although the degree of both is slightly reduced compared with the real-time assay (two additional failed reactions and two incorrect scores).

\section{HRM}

In HRM analyses a small region of DNA containing the mutation of interest is amplified by PCR in the presence of a third generation fluorescent dsDNA dye. The new generation of dyes for this purpose such as SYTO 9 (Invitrogen), LC Green (Idaho Technologies) and Eva Green (Biotium Inc) are less inhibitory to PCR than traditional dyes which allow them to be used at higher concentration to achieve maximum saturation of the resulting dsDNA amplicon. A high resolution melt step is then performed, centered around the $\mathrm{T}_{\mathrm{M}}$ of the amplicon, using machines with high optical and thermal precision. As the dsDNA dissociates into single strands the dye is released and the fluorescence diminishes giving a melt curve profile characteristic of the sequence of the amplicon [33].

The kdr-e mutation (a thymine to cytosine change) is predicted to cause a relatively large change $\left(>0.5^{\circ} \mathrm{C}\right)$ in the melt curve $\mathrm{T}_{\mathrm{M}}$ of the sequence immediately surrounding it. In contrast the $k d r$-w mutation (adenine to thymine) is predicted to cause a very small change in $T_{M}$ in the melt curve making it more difficult to detect. Therefore, initial attempts were focused on optimizing HRM for detection of the $k d r$-e mutation. Using samples of known genotype HRM was able to efficiently distinguish the three possible genotypes. As shown in Figure 5A homozygous individuals were characterized by a shift in the $T_{M}$ of the melt curve whereas heterozygotes by a change in the shape of the melt curve. This change in shape results from destabilized heteroduplex annealing between some of the wild type and variant strands, creating a melt curve profile that is actually a composite of homo- and heteroduplex components [31]. The $k d r$-w mutation was subsequently optimized in the same way using samples of known genotype. As shown in Figure 5B the A/T base change produced a smaller effect on the melt curve profile, nevertheless it was still possible to distinguish homozygous individuals and due to the change in melt curve shape heterozygotes. After 

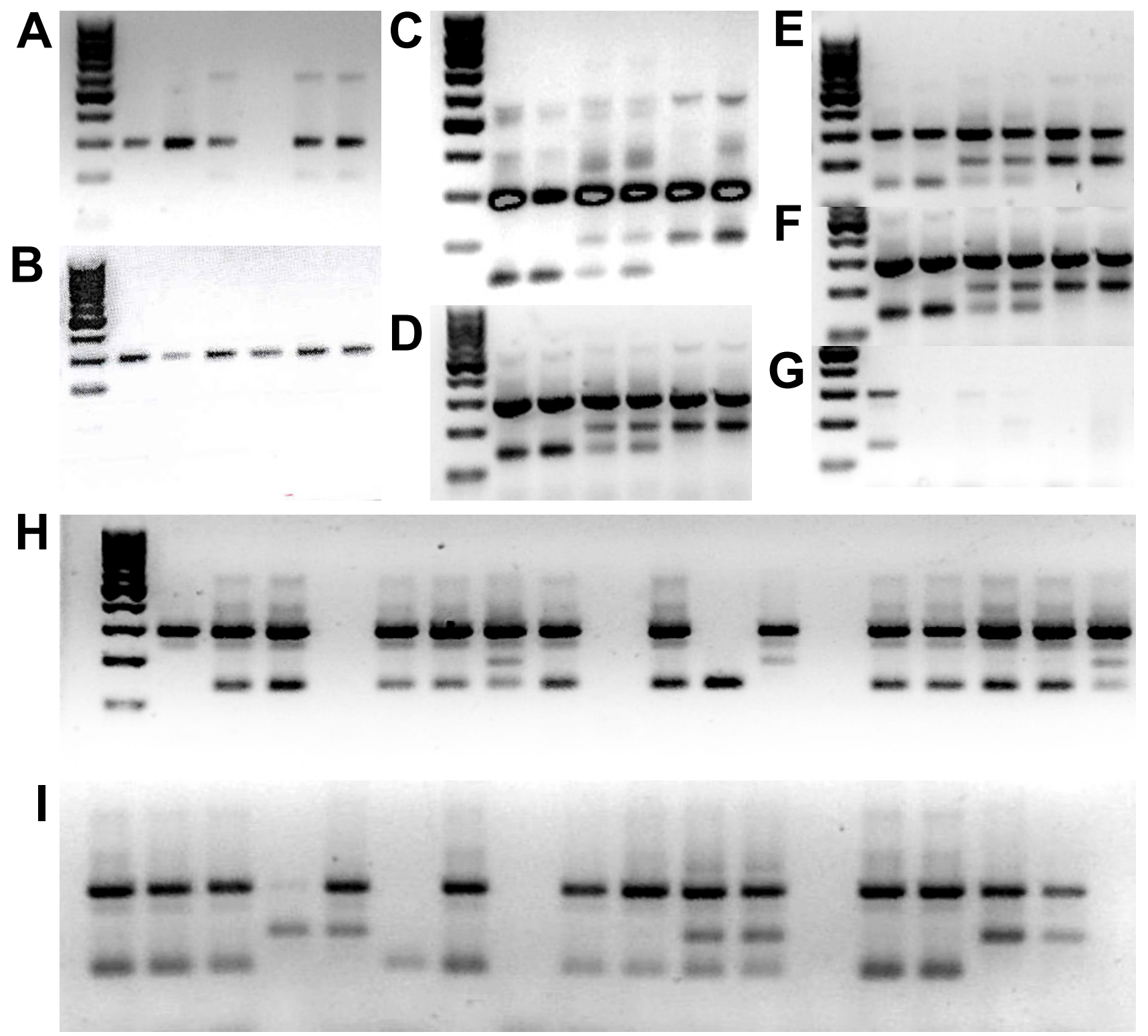

\section{Figure I}

Examples of AS-PCR products for $\boldsymbol{k d r}$-e and $\boldsymbol{k d r}$-w genotyping. Gels $A$ to $D$ show examples of AS-PCR results using four different protocols, A [29], B [I I], C [ I2], D [20]. Gels E to G show the result of using different DNA polymerases on the AS-PCR method described by [20], E: Promega PCR master mix, F: Qiagen HotStar Taq G:Finzymes Dynazyme II Gel H is an example of results of using the protocol of [20] with the Promega PCR master mix to genotype samples using the kdr-e assay from the 96 reference plate and gel I for the $k d r-w$ assay. The same DNA templates were used in PCRs shown in gels A to G and from left to right were 100 bp DNA Ladder (Fermentas), homozygous wildtype, homozygous wildtype, heterozygous, heterozygous, homozygous mutant, homozygous mutant.

these promising results the effect of combining the assays was examined by looking at a number of samples covering all five possible genotypes. The results (Figure 5C) showed that the three homozygous genotypes can be distinguished by the characteristic $\mathrm{T}_{\mathrm{M}}$ shift in the melt curves but it was more difficult to distinguish the two hetero- zygous genotypes as they give similar melt curve shapes. In this case it was easier to score heterozygous individuals using the difference plot function of the Rotor-Gene software which plots the difference in fluorescence of one sample against a chosen reference at each temperature increment (Figure 5D). Despite these promising results 

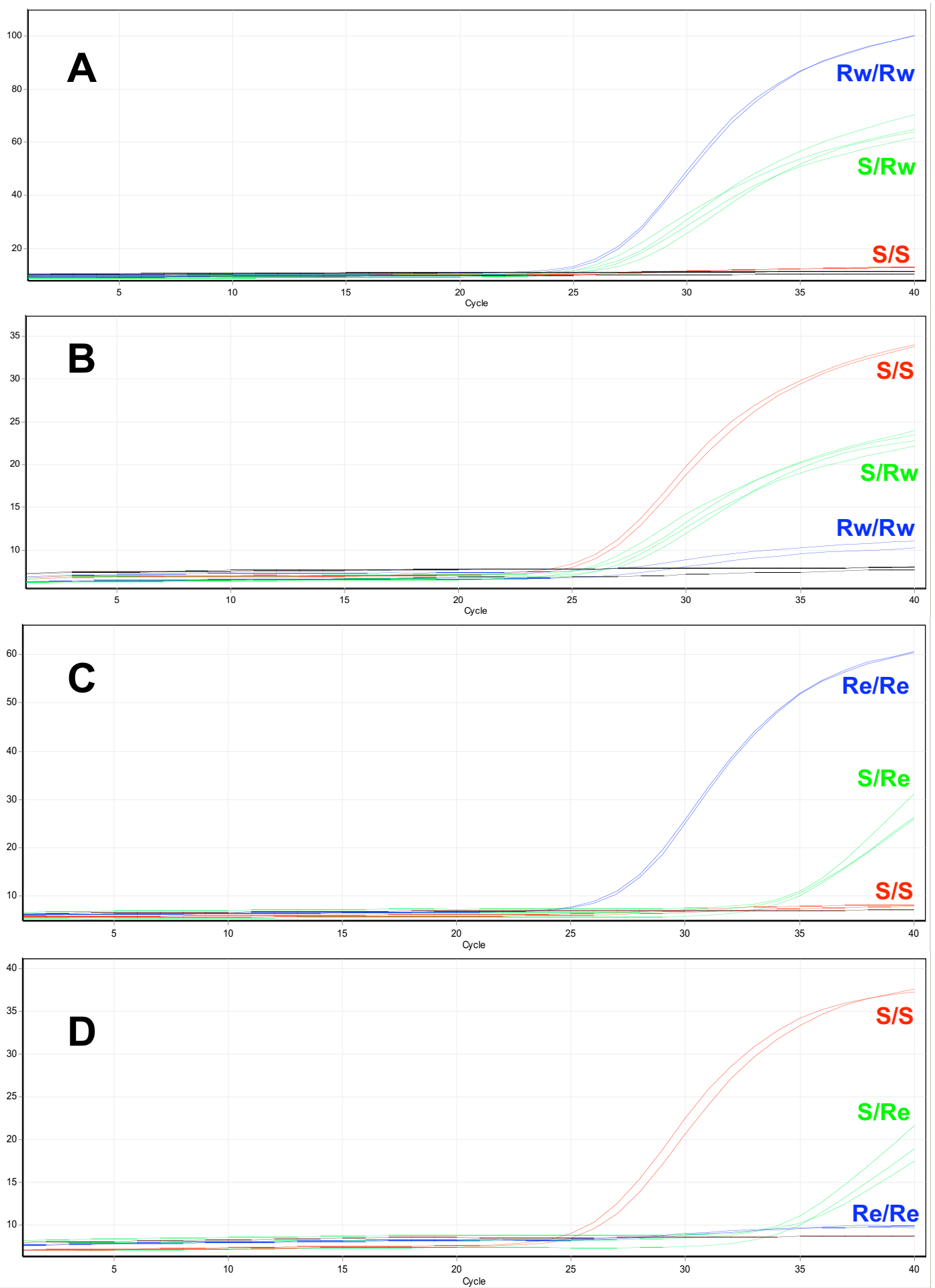

\section{Figure 2}

Real-time TaqMan detection of the kdr-e and kdr-w alleles. A) and B) Detection of the $k d r-w$ mutation. C) and D) Detection of the kdr-e mutation. A) Cycling of FAM-labelled probe specific for the $k d r-w$ allele. C) Cycling of the FAM-labelled probe specific for the kdr-e allele. B) and D) cycling of the VIC labelled probe specific for the wild type allele. S: Wild type allele (LI0I4), Rw: Resistant allele, West African mutation (LI0I4F), Re: Resistant allele, East African mutation (LI0I4S). 


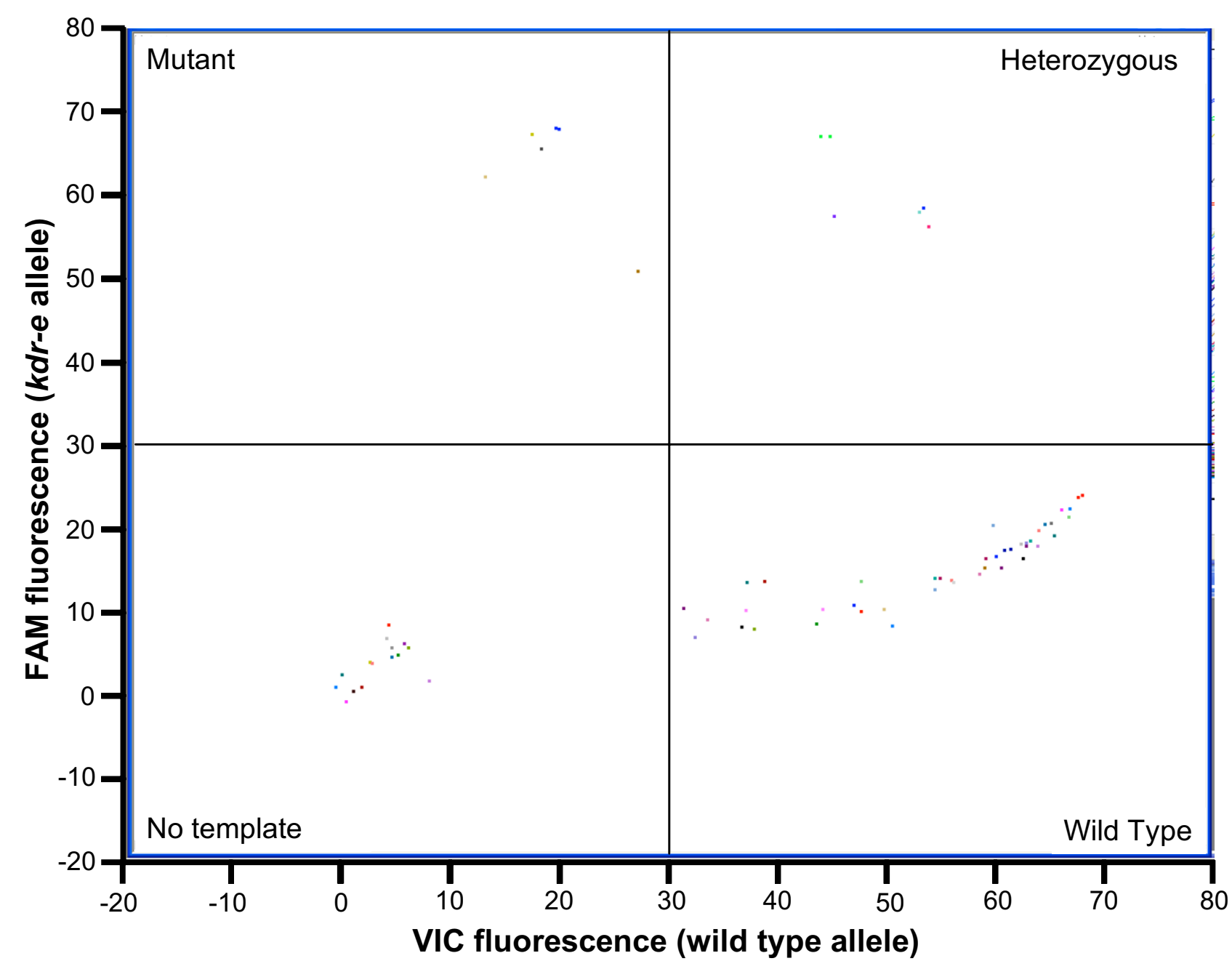

Figure 3

Scatter plot analysis of TaqMan fluorescence data. In this example real time PCR was carried out using the east $k d r$ assay on $\sim 70$ samples from the 96 samples reference plate then fluorescence values of the FAM labelled probe specific for the kdr-e mutation were plotted against the VIC labelled probe specific for the wild type allele.

with template DNAs of known genotype the results of using HRM to genotype the 96 samples in the reference plate were disappointing (see Table 1/Additional file 1) with a high failure rate compared to other assays (16) and a higher number of samples incorrectly scored (7). The high failure resulted from many of the samples amplifying late or failing to reach a high signal plateau in the PCR phase which gives inconclusive or low resolution HRM data. The variable amplification efficiency and incorrect scoring is likely to be due to the quantity and quality of the DNA samples.

\section{SSOP-ELISA}

The SSOP ELISA technique combines a PCR step with subsequent visualization of products using sequence-specific oligonucleotide probes in an ELISA format. Biotinylated PCR products are captured on streptavidin-coated microtiter plates and digoxigenin-labelled sequence-specific oligonucleotide probes (SSOPs) hybridized to the PCR products. A stringent washing procedure precedes the detection of the bound SSOPs using peroxidase-conjugated anti-digoxigenin antibodies. Results can be scored by eye or quantified by spectrophotometry [36].

The results of genotyping the 96 samples in the reference plate using the SSOP-ELISA method are shown in Table $1 /$ Additional file 1 . Overall there were 13 failed reactions, four of which were DNA from An. funestus (which is either very degraded or contains strong inhibitors as described in the TaqMan results section) and 4 from An. merus individ- 


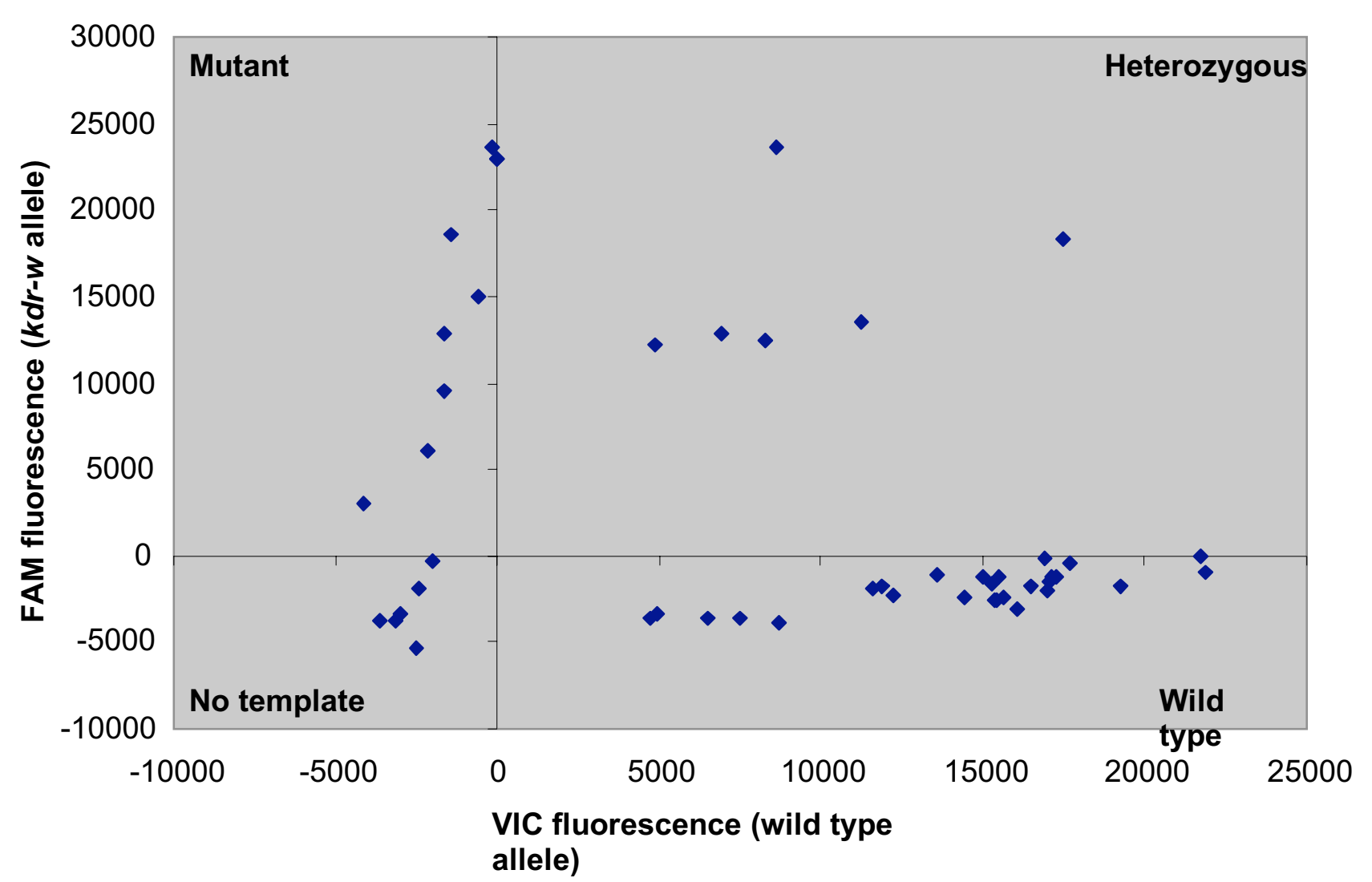

\section{Figure 4}

Scatter plot analysis of TaqMan End point assay using a PCR machine+fluorimeter. In this example PCR was carried out using the west $k d r$ assay from 48 samples of the 96 sample reference plate and the fluorescence of VIC and FAM was measured on a fluorimeter. The data was corrected for background and then plotted in a bi-directional scatter plot in Microsoft Excel. Values of $X$ and $Y$ axes are raw fluorescence values.

uals. The remaining five failed reactions were from $A n$. gambiae DNA. One of these samples also failed in all assays apart from the TaqMan endpoint assay where it was scored as a false positive, another failed in almost all assays except for the TaqMan and the third also failed in the HOLA and HRM methods. There was some betweenexperiment variation in the cut-off OD values of positive and negative controls which may explain the five incorrect results that might have been caused by trivial differences in the strength of probe binding and the washing force during high stringency washes. Overall, the sensitivity and specificity of this method was similar to that displayed by the AS-PCR, PCR-dot blot and HOLA assays.

\section{PCR-Dot Blot}

In the PCR-Dot Blot technique an initial PCR step, in which the DNA region of interest is amplified, is followed with dot-blotting of the products onto nylon membranes which are then probed with allele specific digoxigeninlabelled oligonucleotides. A stringent washing procedure precedes the detection of bound oligos using alkaline phosphatase-conjugated anti-digoxigenin antibodies. Membranes are exposed to chemiluminescent sensitive films and scored visually [37].

The PCR-dot blot hybridization assay has been used previously for the detection of the west $k d r$ and wildtype alleles [24]. Here, a modified protocol using the DIG hybridization and detection system (Roche) for the detection of the wildtype allele and both the east and west $k d r$ alleles is described. A portion of the resulting membranes showing examples of $k d r$ genotyping is shown in Figure 6. The performance of this method in genotyping of the 96 samples in the reference plate is shown in Table 1/Additional file 1 . The sensitivity and specificity of this method was comparable to that demonstrated by the AS-PCR and SSOP-ELISA methods. Of the 12 failed reactions, four were DNA from An. funestus and four from An. merus individuals. The remaining four reactions were DNA from $A n$. gambiae individuals. From these, one reaction also failed 

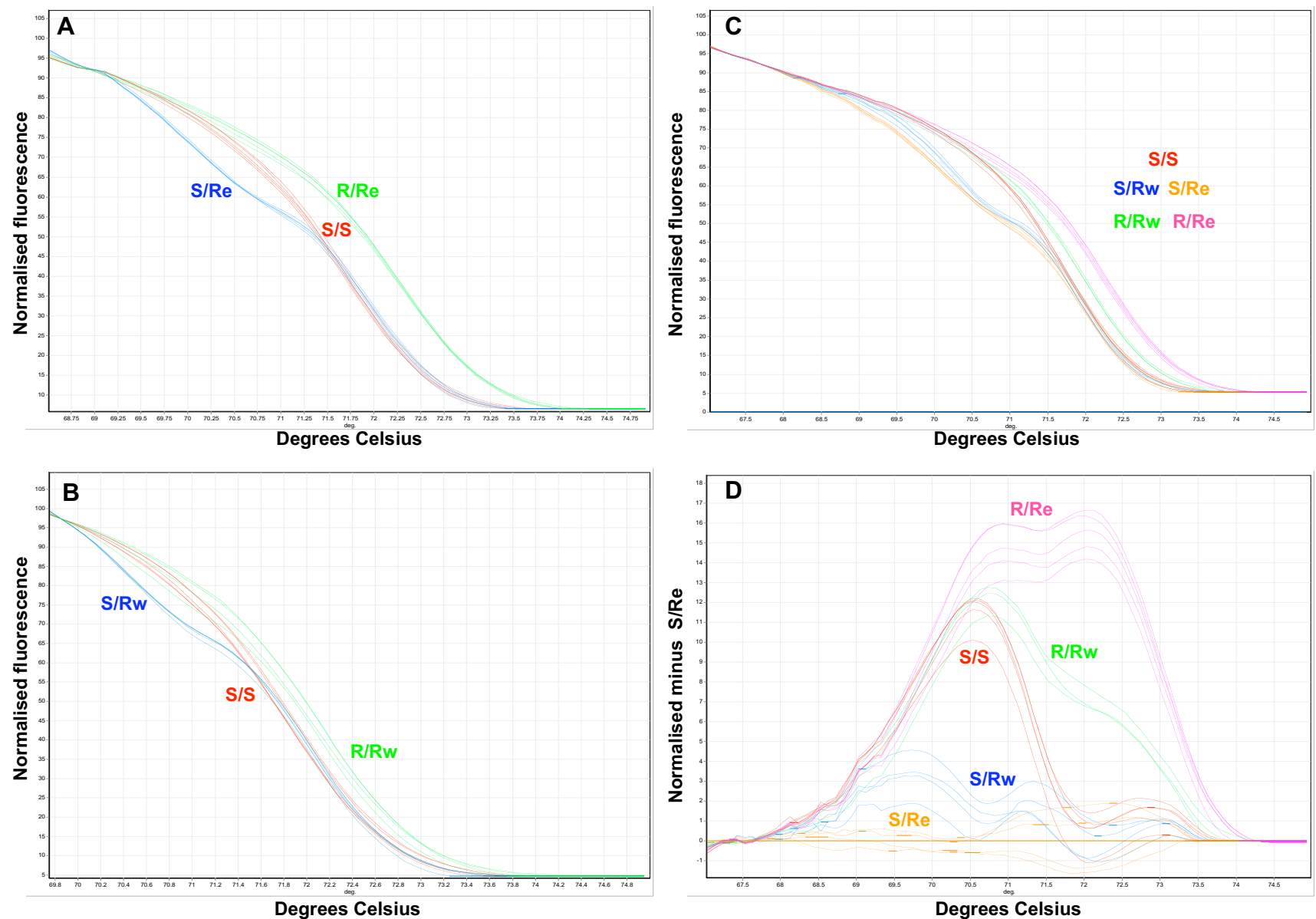

Figure 5

High Resolution Melt (HRM) for detection of kdr-e and kdr-w mutations. A) HRM detection of kdr-e allele. B) HRM detection of $k d r-w$ allele. C) HRM detection for both $k d r-e$ and $k d r-w$ mutations. D) The melt curve profiles shown in $C$ plotted as a difference plot as an aid to visual interpretation. In this case the difference in fluorescence of a sample to a selected control (in this case an S/Re genotype control) is plotted at each temperature transition. S: Wild type allele (LIOI4), Rw: Resistant allele, West African mutation (LIOI4F), Re: Resistant allele, East African mutation (LIOI4S).

in all assays apart from TaqMan, another failed in AS-PCR and the TaqMan endpoint assay and a third failed in all assays except for the TaqMan endpoint assay where it gave a false positive. The forth reaction failed only in the PCR dot-blot assay while an inconclusive result for this reaction was observed in the HRM assay. Incorrect scoring in five instances may be attributed to the higher background caused by differences in the strength of probe binding and the washing force during high stringency washes.

\section{HOLA}

In the HOLA technique an initial PCR step to amplify the region of interest is followed by a hot ligation step during which ligation occurs between biotinylated "allele-specific detector" oligonucleotides and fluorescein-labelled "reporter" oligonucleotides when the 3' detector nucle- otide is complementary to a nucleotide at the SNP locus. Ligated products are then captured in 96-well streptavidin plates, and successful ligation is detected using peroxidase-labelled anti-fluorescein antibodies. Results can be scored by eye or using a 96-well microplate spectrophotometer [38].

The results of the blind genotyping of the 96 samples in the reference plate using the HOLA method are shown in Table 1/Additional file 1 . The results were scored either visually or analysed on an ELISA plate reader. Overall the HOLA method genotyped a similar number of samples correctly as the AS-PCR, SSOP-ELISA and Dot Blot methods. Compared to these other assays there was a lower number of failed reactions (three of which were from $A n$. 


\section{$104 \mathrm{~S}(\mathrm{Re} / \mathrm{Re})$}

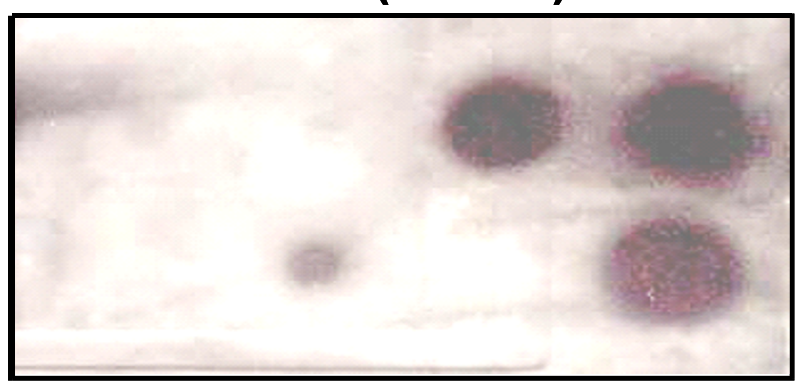

$104 \mathrm{~L}(\mathrm{~S} / \mathrm{S})$

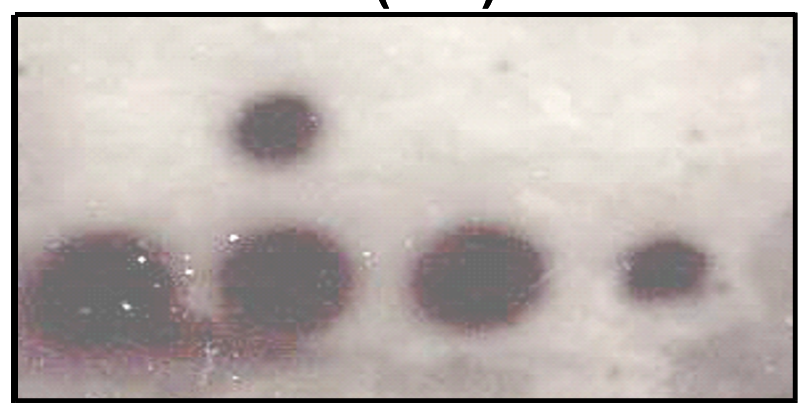

104F (Rw/Rw)

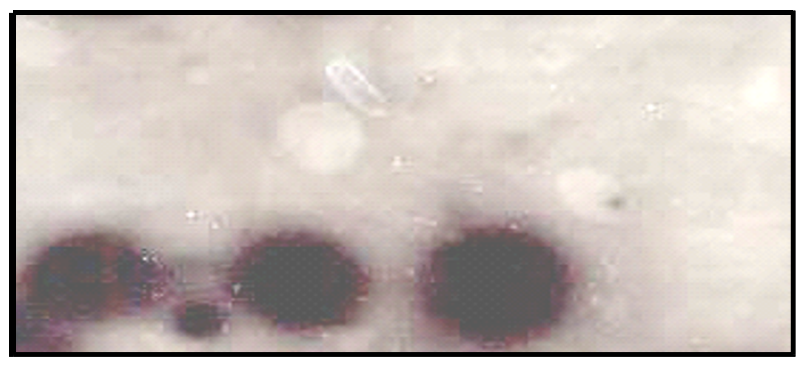

\section{Figure 6}

PCR Dot blot for detection of $k d r-e$ and $k d r-w$ alleles. The same reactions are shown on a portion of three membranes each probed with a different sequence specific oligonucleotide probe, I04S specific for the kdr-e allele, 104L specific for the wild type allele or I04F specific for the $k d r-w$ allele. Reaction products shown are, top row (left to right): no template control, homozygous wild type, homozygous $k d r$-e, homozygous kdr-e, bottom row (left to right): hetero-

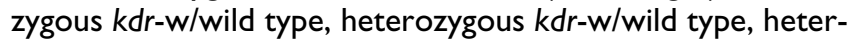

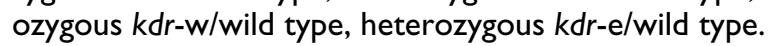

funestus DNA the remainder An. gambiae) but a higher rate of incorrect scores (11 out of 96).

\section{Discussion}

The development of pyrethroid resistance in Anopheles populations has the potential to seriously compromise malaria control efforts. A recent report examining the effectiveness of using ITNs at two sites in Benin has given clear evidence of pyrethroids failing to control an An. gambiae population that contains $k d r$ resistance at high levels [6]. This highlights the need to monitor the spread of resistance conferring alleles and to use this information to devise management strategies to prolong the effective life of the insecticide and to help make decisions on which insecticide class to best use for effective control. There are a number of assays available for genotyping $k d r$ alleles. The most widely used of these in malaria endemic countries is the AS-PCR method, probably due to its relatively low cost (both capital expenditure and running costs) (Table 2); however, a number of recent reports have questioned the reliability of this technique [20,29]. In this study, a number of protocol variations on the basic ASPCR method were followed and the method which gave optimal results is described. The blind genotyping trial showed the AS-PCR method gave a relatively low misscore rate but compared to the TaqMan method it lacked sensitivity with a higher rate of failed reactions. The comparisons given in Table 2 also show other disadvantages of this technique; for example, the potential safety hazard presented by the use of ethidium bromide and the relatively low-throughput compared to TaqMan and HRM.

Other methods with a low initial set-up cost that were investigated in this study were SSOP-ELISA, PCR DOTBLOT and HOLA with all three giving comparable results in the blind genotyping trial. As shown in Table 2 all three assays require only basic equipment (a PCR machine, shaking incubator (ELISA) and, for the ELISA and HOLA methods, an optional ELISA reader). In addition, all dispense with the need for gel electrophoresis making them safer than AS-PCR. On the basis of cost and throughput the SSOP-ELISA method is the front-runner of the three assays. It requires approximately five and a half hours to run (17 steps) and more than 150 samples can be screened for the three $k d r$ alleles in one day. The HOLA method takes approximately six and a half hours (16 steps) and 96 samples can be screened per day if four PCR machines/blocks are used. The PCR dot-blot assay can be completed in approximately 16 hours (16 steps) and more than 150 samples can be screened per day. Analysis of one sample (for the three $k d r$ alleles) costs approximately US \$1 using the SSOP-ELISA method, US\$1.74 using the HOLA method and US\$ 1.6 using the PCR dotblot assay. Overall, the SSOP-ELISA, HOLA and PCR dotblot assays require the use of basic equipment, are relatively cheap and provide acceptable sensitivity/specificity. They are thus amenable to researchers on a limited budget or without access to expensive equipment and are good options for laboratories in developing countries. The limitation of these assays lies in the requirement for a high number of post-PCR steps making them lengthier and of 
Table 2: Comparison of seven assays for kdr genotyping based on specialist equipment required, cost, safety, simplicity of protocol and speed of method. Capital cost was calculated for all assays and is correct at the time of submission. Consumable/running cost was calculated for all assays except for the HOLA and SSOP-ELISA where the running cost listed was obtained from the original report of the method.

\begin{tabular}{|c|c|c|c|c|c|c|c|}
\hline & TaqMan & $\begin{array}{l}\text { TaqMan } \\
\text { Endpoint }\end{array}$ & HRM & $A S-P C R$ & SSOP-ELISA & PCR Dot Blot & HOLA \\
\hline $\begin{array}{l}\text { Specialist } \\
\text { equipment } \\
\text { required }\end{array}$ & $\begin{array}{l}\text { Real-time PCR } \\
\text { machine }\end{array}$ & $\begin{array}{l}\text { PCR thermocyler } \\
\text { Fluorimeter }\end{array}$ & $\begin{array}{l}\text { High-spec real } \\
\text { time PCR machine }\end{array}$ & $\begin{array}{c}\text { PCR thermocycler } \\
\text { Gel } \\
\text { electrophoresis } \\
\text { and imaging } \\
\text { equipment }\end{array}$ & $\begin{array}{l}\text { PCR thermocycler } \\
\text { Shaking incubator } \\
\text { Multichannel } \\
\text { pipette } \\
\text { *optional ELISA } \\
\text { plate reader }\end{array}$ & $\begin{array}{l}\text { PCR thermocycler } \\
\text { Shaking incubator } \\
\text { Multichannel } \\
\text { pipette }\end{array}$ & $\begin{array}{c}\text { PCR thermocycler } \\
\text { Multichannel } \\
\text { pipette } \\
\text { *optional ELISA } \\
\text { plate reader }\end{array}$ \\
\hline $\begin{array}{l}\text { Capital outlay } \\
\text { cost (for } \\
\text { equipment above } \\
\text { given in US\$) }\end{array}$ & $\begin{array}{l}96 \text { well } \$ 25000 \\
48 \text { well } \$ 19000\end{array}$ & $\$ 17800$ & $\$ 50000$ & $\$ 10000$ & $\begin{array}{c}\$ 7600 \\
\text { *optional ELISA } \\
\text { plate reader add } \\
\$ 5000\end{array}$ & $\$ 7600$ & $\begin{array}{c}\$ 5500 \\
\text { *optional ELISA } \\
\text { plate reader add } \\
\$ 5000\end{array}$ \\
\hline $\begin{array}{l}\text { Hazardous } \\
\text { chemicals }\end{array}$ & - & - & - & Ethidium bromide & $\begin{array}{c}\text { TMAC, } \mathrm{H}_{2} \mathrm{SO}_{4} \\
\text { SDS }\end{array}$ & SDS & SDS \\
\hline $\begin{array}{c}\text { Protocol run } \\
\text { time }\end{array}$ & I hr 45 mins & $2 \mathrm{hrs}$ & I hr 35 mins & $\sim 4$ hrs 30 mins & $\sim 5 \mathrm{hrs} 30 \mathrm{mins}$ & $\sim 16-18 \mathrm{hrs}$ & $\sim 6 \mathrm{hrs} 30 \mathrm{mins}$ \\
\hline Number of steps & I & 2 & 1 & 2 & 17 & 16 & 15 \\
\hline $\begin{array}{l}\text { Primers/Probes } \\
\text { required (for } \\
\text { detection of } 3 k d r \\
\text { alleles) }\end{array}$ & $\begin{array}{l}2 \text { PCR primers } \\
3 \text { fluorescently } \\
\text { labelled probes }\end{array}$ & $\begin{array}{l}2 \text { PCR primers } \\
3 \text { fluorescently } \\
\text { labelled probes }\end{array}$ & 2 PCR primers & 5 PCR primers & $\begin{array}{l}2 \text { PCR primers } \\
\text { (one biotin } \\
\text { labelled) } \\
3 \text { SSOPs } \\
\text { (digoxigenin } \\
\text { labelled) }\end{array}$ & $\begin{array}{l}2 \text { PCR primers } \\
3 \text { SSOPs } \\
\text { (digoxigenin } \\
\text { labelled) }\end{array}$ & $\begin{array}{l}2 \text { PCR primers } \\
2 \text { reporter primers } \\
\text { (5'phosphorylation } \\
\text { and } 3 \text { 'fluorescein } \\
\text { labelled) } \\
4 \text { detector primers } \\
\text { (biotin labelled) }\end{array}$ \\
\hline $\begin{array}{l}\text { Number of } \\
\text { tubes/wells/ } \\
\text { membranes } \\
\text { required per } \\
\text { sample }\end{array}$ & 2 & 2 & 1 & 2 & 3 & 3 & 4 \\
\hline $\begin{array}{l}\text { Running cost } \\
\text { (per sample for } \\
\text { three alleles) }\end{array}$ & $\$ 1.72$ & $\$ 1.72$ & $\$ 0.62$ & $\$ 0.92$ & $\operatorname{sim} \$ 1$ & $\$ 1.6$ & $\$ 1.74$ \\
\hline
\end{tabular}

limited throughput capacity compared to the TaqMan and HRM assays. This is also an important consideration where operator time is included as part of the assay cost.

In this study, the performance of the four lower throughput assays was compared with two newly developed assays, TaqMan and HRM. The two high-throughput platforms both represent true closed-tube approaches requiring a single step to achieve results. This is in contrast to two recently developed high-throughput assays for $k d r$ detection, FRET/MCA which requires two rounds of PCR [20] and PCR elongation with fluorescence which requires PCR followed by capillary electrophoresis [25]. HRM is a relatively new technique that has been used very successfully in a number of previous genotyping studies $[32,33]$. Because this method uses standard oligonucleotide primers and has no requirement for fluorescentlylabelled oligonucleotides, the running costs are very low (Table 2). In addition HRM has the potential to identify novel mutations in the region of DNA encompassed by the PCR primers as any alternative base change will alter the melt profile of the amplicon. The HRM method showed initial promise during optimization with templates of known genotype (where DNA concentration was adjusted to be consistent for all samples) but subsequently performed less well in the blind genotyping trial. This is likely explained by variable DNA quality and quantity in the 96 samples in the reference plate, leading to many samples amplifying after 35 cycles or failing to reach full plateau phase. For HRM it is recommended that the amount of DNA template used in PCR be consistent between samples as large differences in starting template will affect the observed Tm. It is, therefore, possible that this assay could be improved if DNA concentration was adjusted. However this constitutes an additional step in the protocol and would require DNA quantification using a spectrophotometer or gel electrophoresis. A comparison of HRM with the other methods (Table 2) highlights the greatest disadvantage which is the capital outlay required. Although HRM has low consumable costs it requires realtime PCR machines of high thermal and optical precision that are significantly more expensive than those that lack this specification. This high initial cost may give this assay limited application for use in resource poor malaria endemic countries.

In contrast to HRM, the TaqMan approach performed very well in the genotyping trial showing the highest level of specificity and sensitivity (as determined by the low number of failed reactions and incorrect scores) of all the assays trialled. This is likely due to both a higher degree of sensitivity and a higher tolerance to variation in DNA quality and quantity than the other assays. The TaqMan method was quick to optimise and along with HRM shows the highest throughput of the assays being simple and quick to setup (Table 2). Results can be scored easily, 
both manually or autoscored. The running cost of the TaqMan assay is slightly higher than the AS-PCR and HRM assays but comparable to the other methods (Table 2). Currently this method uses two separate assays to detect the $k d r$-w and $k d r$-e mutations, in future consumable costs could be further reduced by multiplexing the assay so that the wildtype, $k d r-e$ and $k d r$-w alleles are detected in a single tube using probes with three fluorophores with distinct emission and excitation spectra. The other significant disadvantage of this assay is the capital outlay required, for a 96 well real-time PCR machine which costs in the region of US $\$ 25,000-50,000$. One way to bring this cost down is through the purchase of a 48 well machine (these can be purchased for US $\$ 19,000-21,000$ ) although this entails a reduction in possible throughput. An alternative cost-saving option is to carry out the TaqMan assays using a standard thermocycler for PCR and then measure endpoint fluorescence with a fluorimeter. The results described here show this is a viable approach and although a slight increase in failed reactions and incorrect scores was seen in the blind genotyping trial compared to the real-time assay, this method was still more sensitive and more specific than the AS-PCR, SSOP-ELISA, HOLA, and PCR Dot-Blots assays. A disadvantage of the endpoint method is the requirement for a small degree of data analysis before scoring (subtraction of blank and cut-off values).

Monitoring of resistance alleles such as kdr often involves the processing of thousands of individual insects per site. In this study the performance of these methods was examined on individual mosquitoes, future work could investigate the feasibility of using these assays on pooled insects to further increase throughput. A potential caveat of this approach is that it may not efficiently identify resistance alleles at low levels in mosquito populations particularly if they are present in the heterozygous state.

\section{Conclusion}

There are a number of options available for $k d r$ genotyping. In this comparison of two new high-throughput methods with four previously reported assays the TaqMan method delivered the greatest specificity and sensitivity. However, where cost is the overwhelming factor in assay choice the SSOP-ELISA method is recommended based on cost, ease of use and throughput.

\section{Authors' contributions}

CB developed the TaqMan and HRM techniques, optimized and ran the AS-PCR method and drafted the manuscript. DN optimized and ran the SSOP-ELISA and PCRDot Blot methods and helped draft the manuscript. MJD helped design the study, organized and designed the reference plate of samples and helped draft the manuscript. MSW, HR and JV helped design the study and draft the manuscript. $\mathrm{AB}$ genotyped the reference plate using the HOLA method. LMF helped design the study and helped draft the manuscript. All authors read and approved the final manuscript.

\section{Additional material}

\section{Additional file 1}

Excel spreadsheet showing the details of the 96 sample reference plate and full results of the blind genotyping trial. The genotype assigned to each sample by each assay is shown. S: Wild type allele (L1014), Rw: Resistant allele, West African mutation (L1014F), Re: Resistant allele, East African mutation (L1014S). Negative controls (water or Plasmodium falciparum DNA) are highlighted in grey. Failed reactions are highlighted in blue. Incorrectly scored reactions are highlighted in yellow. Click here for file

[http://www.biomedcentral.com/content/supplementary/14752875-6-111-S1.xls]

\section{Acknowledgements}

We thank Keith Steen for help with the preparation of the reference plate of samples. This study was supported by the Innovative Vector Control Consortium. Rothamsted Research receives grant-aided support from the Biotechnology and Biological Sciences Research Council of the UK.

\section{References}

I. Phillips-Howard PA, Nahlen BL, Kolczak MS, Hightower AW, ter Kuile FO, Alaii JA, Gimnig JE, Arudo J, Vulule JM, Odhacha A, Kachur SP, Schoute E, Rosen DH, Sexton JD, Oloo AJ, Hawley WA: Efficacy of permethrin-treated bed nets in the prevention of mortality in young children in an area of high perennial malaria transmission in western Kenya. Am J Trop Med Hyg 2003, 68:23-29.

2. Binka FN, Kubaje A, Adjuik M, Williams LA, Lengeler C, Maude GH, Armah GE, Kajihara B, Adiamah JH, Smith PG: Impact of permethrin impregnated bednets on child mortality in Kassena-Nankana district, Ghana: A randomized controlled trial. Trop Med Int Health 1996, I:147-154.

3. Choi HW, Breman JG, Teutsch SM, Liu SM, Hightower AW, Sexton JD: The effectiveness of insecticide-impregnated bed nets in reducing cases of malaria infection: $A$ meta-analysis of published results. Am J Trop Med Hyg 1995, 52:377-382.

4. D'Alessandro U, Olaleye BO, McGuire W, Langerock P, Bennett $S$, Aikins MK, Thomson MC, Cham MK, Cham BA, Greenwood BM: Mortality and morbidity from malaria in Gambian children after introduction of an impregnated bednet program. Lancet 1995, 345:479-483.

5. Vulule JM, Beach RF, Atieli FK, Roberts JM, Mount DL, Mwangi RW: Reduced susceptibility of Anopheles gambiae to permethrin associated with the use of permethrin-impregnated bednets and curtains in Kenya. Med Vet Entomol 1994, 8:71-75.

6. N'Guessan R, Corbel V, Akogbeto M, Rowland M: Reduced efficacy of insecticide-treated nets and indoor residual spraying for malaria control in pyrethroid resistance area, Benin. Emerg Inf Dis 2007, 13(2): 199-206.

7. Narahashi $\mathrm{T}$ : Nerve membrane $\mathbf{N a}+$ channels as targets of insecticides. Trends Pharmacol Sci 1992, 13:236-24l.

8. Soderlund DM, Bloomquist JR: Neurotoxic actions of pyrethroid insecticides. Annu Rev Entomol 1989, 34:77-96.

9. Busvine JR: Mechanisms of resistance to insecticides in houseflies. Nature 1951, 168:193-195.

10. Williamson MS, Martinez-Torres D, Hick CA, Devonshire AL: Identification of mutations in the housefly para-type sodium channel gene associated with knockdown resistance $(k d r)$ to pyrethroid insecticides. Mol Gen Genet 1996, 252:51-60. 
II. Ranson H, Jensen B, Vulule JM, Wang X, Hemingway J, Collins FH: Identification of a point mutation in the voltage-gated sodium channel gene of Kenyan Anopheles gambiae associated with resistance to DDT and pyrethroids. Insect Mol Biol 2000, 9:49|-497.

12. Martinez-Torres D, Chandre F, Williamson MS, Darriet F, Berge JB, Devonshire AL, Guillet P, Pasteur N, Pauron D: Molecular characterization of pyrethroid knockdown resistance (kdr) in the major malaria vector Anopheles gambiae s.s. Insect Mol Biol 1998, 7:179-184.

13. Diabate A, Baldet T, Chandre E, Dabire KR, Simard F, Ouedraogo JB, Guillet P. Hougard JM: First report of a kdr mutation in Anopheles arabiensis from Burkina Faso, West Africa. J Am Mosq Control Assoc 2004, 20: 195- I 96.

14. Stump AD, Atieli FK, Vulule JM, Besansky NJ: Dynamics of the pyrethroid knockdown resistance allele in western Kenyan populations of Anopheles gambiae in response to insecticidetreated bed net trials. Am J Trop Med Hyg 2004, 70:59I-596.

15. Awolola TS, Oyewole IO, Amajoh CN, Idowu ET, Ajayi MB, Oduola A, Manafa OU, Ibrahim K, Koekemoer LL, Coetzee M: Distribution of the molecular forms of Anopheles gambiae and pyrethroid knock down resistance gene in Nigeria. Acta Trop 2005, 95:204-209.

16. Yawson AE, McCall PJ, Wilson MD, Donnelly MJ: Species abundance and insecticide resistance of Anopheles gambiae in selected areas of Ghana and Burkina Faso. Med Vet Entomol 2004, 18:372-377.

17. Fanello C, Petrarca V, della Torre A, Santolamazza F, Dolo G, Coulibaly M, Alloueche A, Curtis CF, Toure YT, Coluzzi M: The pyrethroid knock-down resistance gene in the Anopheles gambiae complex in Mali and further indication of incipient speciation within An. gambiae s.s. Insect Mol Biol 2003, I 2:24I-245.

18. della Torre A, Fanello C, Akogbeto M, Dossou-yovo J, Favia G, Petrarca $\vee$, Coluzzi M: Molecular evidence of incipient speciation within Anopheles gambiae s.s. in West Africa. Insect Mol Biol 2001, 10:9-18.

19. Diabate A, Brengues C, Baldet T, Dabire KR, Hougard JM, Akogbeto M, Kengne P, Simard F, Guillet P, Hemingway J, Chandre F: The spread of the Leu-Phe kdr mutation through Anopheles gambiae complex in Burkina Faso: genetic introgression and de novo phenomena. Trop Med Int Health 2004, 9: I267-I 273.

20. Verhaeghen K, Van Bortel W, Roelants P, Backeljau T, Coosemans M: Detection of the East and West African kdr mutation in Anopheles gambiae and Anopheles arabiensis from Uganda using a new assay based on FRET/Melt Curve analysis. Malar J 2006, 5:16.

21. Etang J, Fondjo E, Chandre F, Morlais I, Brengues C, Nwane P, Chouaibou M, Ndjemai H, Simard F: Short report: First report of knockdown mutations in the malaria vector Anopheles gambiae from Cameroon. Am J Trop Med Hyg 2006, 74:795-797.

22. Lynd A, Ranson H, McCall PJ, Randle NP, Black WC, Walker ED, Donnelly MJ: A simplified high-throughput method for pyrethroid knock-down resistance (kdr) detection in Anopheles gambiae. Malar J 2005, 4: I6.

23. Kulkarni MA, Rowland M, Alifrangis M, Mosha FW, Matowo J, Malima R, Peter J, Kweka E, Lyimo I, Magesa S, Salanti A, Rau ME, Drakeley $C$ : Occurrence of the leucine-to-phenylalanine knockdown resistance (kdr) mutation in Anopheles arabiensis populations in Tanzania, detected by a simplified high-throughput SSOPELISA method. Malar J 2006, 5:56.

24. Kolaczinski JH, Fanello C, Herve JP, Conway DJ, Carnevale P, Curtis CF: Experimental and molecular genetic analysis of the impact of pyrethroid and non-pyrethroid insecticide impregnated bednets for mosquito control in an area of pyrethroid resistance. Bull Entomol Res 2000, 90:125-132.

25. Tripet F, Wright J, Lanzaro G: $\mathbf{A}$ new high-performance $\mathbf{P C R}$ diagnostic for the detection of pyrethroid knockdown resistance kdr in Anopheles gambiae. Am J Trop Med Hyg 2006, 74:658-662.

26. Livak KJ: Organization and mapping of a sequence on the Drosophila melanogaster $\mathbf{X}$-chromosome and $Y$-chromosome that is transcribed during spermatogenesis. Genetics 1984, 107:61 I-634.

27. Ballinger-Crabtree ME, Black WC, Miller BR: Use of genetic polymorphisms detected by the Random-Amplified Polymorphic DNA-Polymerase Chain Reaction (RAPD-PCR) for differen- tiation and identification of Aedes aegypti subspecies and populations. Am J Trop Med Hyg 1992, 47:893-901.

28. Scott JA, Brogdon WG, Collins FH: Identification of single specimens of the Anopheles gambiae complex by the polymerase chain reaction. Am J Trop Med Hyg 1993, 49:520-529.

29. Pinto J, Lynd A, Elissa N, Donnelly MJ, Costa C, Gentile G, Caccone A, Do Rosario VE: Co-occurrence of East and West African kdr mutations suggests high levels of resistance to pyrethroid insecticides in Anopheles gambiae from Libreville, Gabon. Med Vet Entomol 2006, 20:27-32.

30. Afonina I, Zivarts M, Kutyavin I, Lukhtanov E, Gamper H, Meyer RB: Efficient priming of PCR with short oligonucleotides conjugated to a minor groove binder. Nucleic Acids Res 1997, 25:2657-2660.

31. High Resolution Melt Assay Design and Analysis CorProtocol 6000-I-July06 [http://www.corbettlifescience.net/public/RotorGene\%206000/hrm corprotocol.pdf].

32. Krypuy M, Newnham GM, Thomas DM, Conron M, Dobrovic A High resolution melting analysis for the rapid and sensitive detection of mutations in clinical samples: KRAS codon 12 and 13 mutations in non-small cell lung cancer. BMC Cancer 2006, 6:295.

33. Liew M, Pryor R, Palais R, Meadows C, Erali M, Lyon E, Wittwer C: Genotyping of single-nucleotide polymorphisms by high-resolution melting of small amplicons. Clin Chem 2004, 50: II56-II64.

34. Liu Q, Thorland EC, Heit JA, Sommer SS: Overlapping PCR for bidirectional PCR amplification of specific alleles: $A$ rapid one-tube method for simultaneously differentiating homozygotes and heterozygotes. Genome Res 1997, 7:389-398.

35. Livak KJ: Allelic discrimination using fluorogenic probes and the 5' nuclease assay. Genetic Anal 1999, 14:143-149.

36. Alifrangis M, Enosse S, Pearce R, Drakeley C, Roper C, Khalil IF, Nkya W, Ronn AM, Theander TG, Bygjerg IBC: A simple, high-throughput method to detect Plasmodium falciparum single nucleotide polymorphisms in the dihydrofolate reductase, dihydropteroate synthase, and $P$. falciparum chloroquine resistance transporter genes using polymerase chain reaction- and enzyme-linked immunosorbent assay-based technology. Am J Trop Med Hyg 2005, 72: I55- 162.

37. Abdel-Muhsin AMA, Ranford-Cartwright LC, Medani AR, Ahmed S, Suleiman S, Khan B, Hunt P, Walliker D, Babiker HA: Detection of mutations in the Plasmodium falciparum dihydrofolate reductase (dhfr) gene by dot-blot hybridization. Am J Trop Med Hyg 2002, 67:24-27.

38. Black WC, Gorrochotegui-Escalante N, Duteau NM: Heated oligonucleotide ligation assay (HOLA): An affordable single nucleotide polymorphism assay. I Med Entomol 2006, 43:238-247.
Publish with BioMed Central and every scientist can read your work free of charge

"BioMed Central will be the most significant development for disseminating the results of biomedical research in our lifetime. "

Sir Paul Nurse, Cancer Research UK

Your research papers will be:

- available free of charge to the entire biomedical community

- peer reviewed and published immediately upon acceptance

- cited in PubMed and archived on PubMed Central

- yours - you keep the copyright
BioMedcentral 